\title{
Differential effects of isoproterenol on the activity of angiotensin-converting enzyme in the rat heart and aorta
}

\section{V.C.W. Busatto ${ }^{1}$, \\ V. Cunha ${ }^{2}$ \\ M.A. Cicilini \\ and J.G. M ill2}

\author{
Departamento de ${ }^{1}$ Biologia and ${ }^{2}$ Ciências Fisiológicas, \\ Universidade Federal do Espírito Santo, Vitória, ES, Brasil
}

\section{Correspondence \\ J.G. Mill \\ Departamento de Ciências \\ Fisiológicas, UFES \\ Av. Marechal Campos, 1468 \\ 29040-090 Vitória, ES \\ Brasil \\ Fax: + 55-27-335-7330}

Research supported by $\mathrm{CNPq}$ (No. 522.733/95-6) and FINEP (No. 76.970792.00)

Received May 19, 1998 Accepted November 19, 1998

\section{Abstract}

The excessive stimulation of beta-adrenergic receptors in the heart induces myocardial hypertrophy. There are several experimental data suggesting that this hypertrophy may also depend, at least partially, on the increase of local production of angiotensin II secondary to the activation of the cardiac renin-angiotensin system. In this study we investigated the effects of isoproterenol on the activity of angiotensinconverting enzyme (ACE) in the heart and also in the aorta and plasma. Male Wistar rats weighing 250 to $305 \mathrm{~g}$ were treated with a dose of $( \pm)$ isoproterenol $\left(0.3 \mathrm{mg} \mathrm{kg}^{-1} \mathrm{day}^{-1}, \mathrm{~N}=8\right)$ sufficient to produce cardiac hypertrophy without deleterious effects on the pumping capacity of the heart. Control rats $(\mathrm{N}=7)$ were treated with vehicle (corn oil). The animals were killed one week later. ACE activity was determined in vitro in the four cardiac chambers, aorta and plasma by a fluorimetric assay. A significant hypertrophy was observed in both ventricular chambers. ACE activity in the atria remained constant after isoproterenol treatment. There was a significant increase $(\mathrm{P}<0.05)$ of ACE activity in the right ventricle $\left(6.9 \pm 0.9\right.$ to $8.2 \pm 0.6 \mathrm{nmol} \mathrm{His-Leu} \mathrm{g}^{-1}$ $\left.\mathrm{min}^{-1}\right)$ and in the left ventricle $\left(6.4 \pm 1.1\right.$ to $8.9 \pm 0.8 \mathrm{nmol} \mathrm{His-Leu} \mathrm{g}^{-1}$ $\left.\mathrm{min}^{-1}\right)$. In the aorta, however, ACE activity decreased $(\mathrm{P}<0.01)$ after isoproterenol $\left(41 \pm 3\right.$ to $\left.27 \pm 2 \mathrm{nmol} \mathrm{His-Leu} \mathrm{g}^{-1} \mathrm{~min}^{-1}\right)$ while it remained unchanged in the plasma. These data suggest that ACE expression in the heart can be increased by stimulation of betaadrenoceptors. However, this effect is not observed on other local renin-angiotensin systems, such as the aorta. Our data also suggest that the increased sympathetic discharge and the elevated plasma concentration of catecholamines may contribute to the upregulation of ACE expression in the heart after myocardial infarction and heart failure.

The endocrine renin-angiotensin system (RAS) has been shown to play an important role for the long-term regulation of blood pressure and body fluid homeostasis. The degree of activation of this endocrine RAS is determined mainly by adjusting the renin synthesis in the kidneys (1). More recently,
Key words

- Angiotensin-converting enzyme

- Isoproterenol

- Cardiac hypertrophy

- Myocardial infarction

- Heart failure local RAS have been described in the heart, adrenal gland, central nervous system, and blood vessels with important paracrine/autocrine functions (2). The main effector of all these RAS is angiotensin II, an octapeptide generated mainly by angiotensin-converting enzyme (ACE). Soluble ACE is also 
present in the plasma and, as an ectoenzyme, it is also found bound to the cell membrane of endothelial cells, fibroblast-like cells, macrophages, and epithelial cells (3).

Despite the importance of ACE for the systemic and local generation of angiotensin II, little is known about the factors involved in the regulation of the expression of this enzyme. An upregulation of the cardiac RAS occurs in some pathophysiological states, such as myocardial infarction and heart failure, with an increased expression of mRNAs encoding angiotensinogen (4) and angiotensin $\mathrm{AT}_{1}$ receptors (5). ACE activity also increases in the heart after infarction (6), mainly in the scar tissue $(7,8)$. The factors responsible for ACE activation after infarction remain unknown.

Experimental evidence suggests that the sympathetic nervous system may influence ACE activity in the heart. An increased concentration of angiotensin II was observed in the heart of rats treated with isoproterenol (9). Moreover, the use of ACE inhibitors prevented the cardiac hypertrophy secondary to the reflex activation of the sympathetic pathways to the heart following sinoaortic denervation in rats (10). More recently an increased expression of the ACE gene was observed in cultures of endothelial cells stimulated with cAMP (11) and Ogiku et al. (12) reported an increased expression of mRNA for ACE in the rat heart after oneweek treatment with isoproterenol. The higher dose of isoproterenol used in this latter study (12), however, also induced heart failure, a condition that activates all the RAS cascade in the heart (4-8). Therefore, the present study was undertaken to investigate the changes of ACE activity in heart, aorta and plasma of rats submitted to a small dose of isoproterenol which is not sufficient to produce a mechanical impairment of cardiac function.

The experiments were performed on male Wistar rats weighing 250 to $305 \mathrm{~g}$ at the onset of the study. The animals were ran- domly assigned to treatment with a daily subcutaneous injection of $( \pm)$-isoproterenol hydrochloride (Sigma Chemical Co., St. Louis, MO, USA) $\left(0.3 \mathrm{mg} \mathrm{kg}^{-1}\right.$ day $\left.^{-1}, \mathrm{~N}=8\right)$ or vehicle (corn oil, $\mathrm{N}=7$ ). One week later the animals were anesthetized with urethane $(1 \mathrm{~g} / \mathrm{kg}, i p)$ and instrumented to record the hemodynamic parameters. The right jugular vein and the right carotid artery were cannulated with polyethylene catheters (PE 50) connected to pressure transducers (Statham PXL23AA) and advanced into the right and left ventricular cavities to record the ventricular systolic and end-diastolic pressures, respectively. The arterial blood pressure was recorded in the ascending aorta. Pressures were amplified (Funbec MP100) and recorded on a chart recorder (Funbec RG 300). All hemodynamic variables were measured after an adequate stabilization period and the individual values for each animal represent the mean value observed in eight to ten consecutive cardiac cycles recorded under conditions of regular rhythm. Hemodynamic values were obtained $24 \mathrm{~h}$ after the last isoproterenol administration.

After hemodynamic recordings, a blood sample ( $2 \mathrm{ml}$ in $50 \mathrm{IU}$ heparin) was collected from the ascending aorta to determine ACE activity in plasma. The rats were then killed by decapitation, the heart was excised and the surrounding fat and fibrous tissue were trimmed away. The four cardiac chambers were separated, blotted and weighed, the interventricular septum being considered as part of the left ventricle. The muscle fragments were minced into small pieces with scissors, diluted $(5 \mathrm{x})$ in a buffered solution of $50 \mathrm{mM}$ sodium borate prepared in $32 \mathrm{mM}$ sucrose, $\mathrm{pH} 7.4$, and homogenized mechanically in a glass homogenizer (Gla-Col Mod 099C-K44) at $3000 \mathrm{rpm}$. The homogenates were centrifuged at $1000 \mathrm{~g}$ for $5 \mathrm{~min}$ at $4^{\circ} \mathrm{C}$ and stored at $-22^{\circ} \mathrm{C}$ until the ACE assay. The whole aorta was also dissected, blotted, and weighed and the homogenates were prepared following the same procedures. The blood 
sample was centrifuged for $10 \mathrm{~min}$ at $2000 \mathrm{~g}$ and the plasma stored at $-22^{\circ} \mathrm{C}$.

ACE activity in tissue homogenates and in plasma was determined by a modified (13) fluorimetric method developed by Friedland and Silverstein (14). Briefly, 100 $\mu 1$ of the tissue homogenates or $10 \mu \mathrm{l}$ of plasma was incubated at $37^{\circ} \mathrm{C}$ in $2 \mathrm{ml}$ of 0.4 $\mathrm{M}$ sodium borate buffer, $\mathrm{pH}$ 8.3, containing 5 mM Hyp-His-Leu (Sigma), a synthetic substrate for ACE. The enzyme reaction was stopped 15 min later with $\mathrm{NaOH}(1.2 \mathrm{ml}$; $0.34 \mathrm{~N})$. An $o$-phthaldialdehyde aliquot (100 $\mu \mathrm{l})$ diluted in methanol $(20 \mathrm{mg} / \mathrm{ml})$ was added to the reaction medium for $10 \mathrm{~min}$ and the reaction was then stopped with $200 \mu \mathrm{l}$ of $3 \mathrm{~N}$ $\mathrm{HCl}$. After centrifugation the dipeptide HisLeu released during the enzyme reaction was measured fluorimetrically in the supernatant by using 365 -nm excitation and $495-$ nm emission (Hitachi Fluorimeter, F-2000). A calibration curve for His-Leu at concentrations from 0 to $40 \mathrm{nmol} / \mathrm{ml}$ was used as standard. ACE activity was corrected according to the tissue mass in cardiac and aorta homogenates and expressed as nmol His-Leu $\mathrm{g}^{-1} \mathrm{~min}^{-1}$. In plasma, ACE activity was corrected according to plasma volume and expressed as nmol His-Leu $\mathrm{ml}^{-1} \mathrm{~min}^{-1}$. In the aortic homogenates the total protein concentration was determined by using the method of Lowry, using bovine serum albumin (Sigma) as standard.

Results are reported as means \pm standard error of the mean (SEM). The two-tailed Student $t$-test for independent samples was used to assess significant differences between groups. The Pearson correlation coefficient (r) was calculated using a linear model according to the least squares method. $\mathrm{P}$ values $<0.05$ were considered to indicate a statistically significant difference between groups.

Infusion of isoproterenol has been shown to induce cardiac hypertrophy which is not mediated by an increased afterload (15). In our study the injection of isoproterenol for one week induced a significant increase in right and left ventricular weights without significant changes in systemic blood pressure (Table 1). Relative increases of the ventricular weights were similar in the right and left ventricle $(34 \pm 4$ and $33 \pm 3 \%$, respectively, $\mathrm{P}>0.05$ ). A small increase of the atrial weights was also observed, which, however, was not significant (right atrium: $35 \pm 4$ to $40 \pm 2 \mathrm{mg}$; left atrium: $23 \pm 2$ to 27 $\pm 2 \mathrm{mg}$ ). Since the relative weight increased similarly in both ventricles we can suppose that the isoproterenol-mediated cardiac hypertrophy depends on agents acting at the same time in both ventricular chambers. The only hemodynamic parameter affected in the isoproterenol-treated group was the right ventricular systolic pressure (Table 1). However, no significant correlation $(r=0.32$, $\mathrm{P}>0.05$ ) between the peak pressure in this chamber and right ventricular hypertrophy was observed. Otherwise, a significant linear correlation between the relative increments of the left ventricular weight and the right ventricular weight $(\mathrm{r}=0.78 ; \mathrm{P}<0.05)$ was observed. This finding reinforces the view that chemical agents may exert a key role for the development of the isoproterenol-mediated hypertrophy. However, an increase in cardiac output due to beta-adrenergic stimulation may also contribute to the cardiac growth. Isoproterenol was always

Table 1 - Morphologic and hemodynamic data for the control and isoproterenol-treated rats.

Data are reported as means \pm SEM. LV, Left ventricle; RV, right ventricle. $* P<0.05$ vs control group (Student t-test).

Control group $(\mathrm{N}=7) \quad$ Isoproterenol group $(\mathrm{N}=8)$

$\begin{array}{lrc}\text { Body weight }(\mathrm{g}) & 291 \pm 23 & 281 \pm 18 \\ \text { RV weight }(\mathrm{mg}) & 162 \pm 9 & 216 \pm 16^{*} \\ \text { LV weight }(\mathrm{mg}) & 632 \pm 58 & 839 \pm 48^{*} \\ \text { Heart rate }(\mathrm{bpm}) & 323 \pm 14 & 325 \pm 20 \\ \text { Mean blood pressure }(\mathrm{mmHg}) & 80 \pm 6 & 75 \pm 6 \\ \text { LV systolic pressure }(\mathrm{mmHg}) & 98 \pm 7 & 92 \pm 5 \\ \text { LV end-diastolic pressure }(\mathrm{mmHg}) & 6 \pm 0.5 & 8 \pm 0.3 \\ \text { RV systolic pressure }(\mathrm{mmHg}) & 25 \pm 1 & 33 \pm 3^{*} \\ \text { RV end-diastolic pressure }(\mathrm{mmHg}) & 5 \pm 0.8 & 6 \pm 0.4\end{array}$


injected in the morning and the hemodynamic data were recorded at least $24 \mathrm{~h}$ after the last injection. Presumably the increase in cardiac output blunted the arterial hypotension usually observed during isoproterenol treatment.

The elevation of cyclic AMP, the second messenger of isoproterenol action in betaadrenoceptors, stimulates protein synthesis in the adult rat heart and contributes to myocyte hypertrophy (16). However, it is likely that this is not the only mechanism to induce hypertrophy in the heart. Several experimental data suggest that the expression of hypertrophy during isoproterenol treatment is also dependent on a direct effect of angiotensin II on the myocytes. Thus, isoproterenol increases left ventricular weight and left ventricular angiotensin II concentration even in nephrectomized rats (9), suggesting that the activation of the local RAS in the heart may contribute to the isoproterenol-induced hypertrophy. Moreover, the tissue concentration of angiotensin II increases in the heart during isoproterenol infusion of isolated heart preparations (9). Thus, the activation of the local RAS mediated by isoproterenol could be an important end-mechanism mediating this hypertrophy. The experimental data observed in our study agree with this hypothesis.

Figure 1 shows ACE activity measured in the four cardiac chambers in control and isoproterenol-treated rats. In the control group, ACE activity followed the well-known pattern, with the highest ACE activity occur-

Figure 1 - Angiotensin-converting enzyme (ACE) activity in the homogenates of the right atrium (RA), left atrium (LA), right ventricle (RV) and left ventricle (LV) of control rats (black bars, $\mathrm{N}=7$ ) and isoproterenol-treated rats (gray bars, $\mathrm{N}=8$ ). $* \mathrm{P}<0.05$ vs control group (Student t-test).

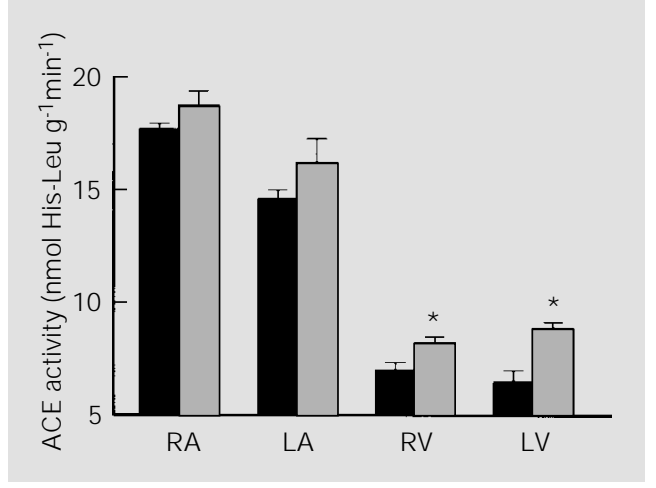

ring in the right atrium and the lowest in the left ventricle $(6,8)$. Isoproterenol induced a slight and nonsignificant increase of ACE activity in both atria. In the ventricles, however, there was a significant increase of ACE activity in the isoproterenol-treated group, mainly in the left ventricle. After isoproterenol, ACE activity increased from $6.9 \pm 0.9$ to $8.2 \pm 0.6$ nmol His-Leu g ${ }^{-1} \mathrm{~min}^{-1}(\mathrm{P}<0.05)$ in the right ventricular free wall and from 6.4 \pm 1.1 to $8.9 \pm 0.8$ nmol His-Leu g ${ }^{-1} \min ^{-1}$ $(\mathrm{P}<0.01)$ in the left ventricle. It is noteworthy that the relative increment of ACE activity in the left ventricle (39\%) was similar to the hypertrophic growth observed in this heart chamber.

The increase of ACE activity in the heart after isoproterenol was not demonstrable in the aorta or in plasma. In the latter, ACE activity remained unchanged (control group $=173 \pm 17$; isoproterenol-treated group $=$ $174 \pm 10$ nmol His-Leu ml-1 min $^{-1} ; \mathrm{P}>0.05$ ) while in the aorta ACE activity was approximately $20 \%$ lower in the isoproterenol group compared with the controls (Figure 2). This finding probably explains why the concentration of angiotensin II remained unchanged in the aorta of nephrectomized rats treated with isoproterenol while the concentration of this peptide in the heart increased (9). Since the wet weight of the aorta was slightly lower in the isoproterenol-treated group (39 $\pm 3.5 \mathrm{mg}$ ) than in the control group ( $48 \pm 3.8$ $\mathrm{mg}$ ), the ACE activity calculated for the whole aorta was nearly $35 \%$ lower in the isoproterenol group compared with the control group $(27.2 \pm 2.2 v s 41.4 \pm 2.9 \mathrm{nmol}$ HisLeu $\mathrm{g}^{-1} \mathrm{~min}^{-1}$, respectively; $\left.\mathrm{P}<0.01\right)$. A similar reduction of ACE activity in the aorta was also observed when the enzyme activity was corrected for the total protein content of tissue homogenates.

The present data suggest that the increased local production of angiotensin II in the heart may account, at least partially, for the cardiac hypertrophy induced by isoproterenol. This explains the antihypertrophic effects of 
ACE inhibitors on this model of cardiac hypertrophy (17). In addition, our results suggest that the induction of cardiac reninangiotensin system may make a significant contribution to the rapid development of cardiac hypertrophy in the presence of sympathetic hyperactivity, such as in sinoaortic denervated rats, mainly because in this case there is only a small and transient increase in cardiac afterload (18). It is noteworthy that the administration of captopril prevented the development of hypertrophy in sinoaortic denervated rats with minimal interference with blood pressure levels (10). Since the sympathetic activity directed at the heart also increases after myocardial infarction (19), we may speculate that the sympathetic hyperactivity may also contribute to increasing ACE expression in the heart during the early phases of myocardial infarction, mainly when heart failure is present $(4,5)$. Recent data from our laboratory have shown that ACE activity in the rat aorta decreases after infarction in rats (Mill JG and Cunha V, unpublished results) while it increases in the heart, mainly in the left ventricle $(6,8)$.

Our results represent an indication that the expression of the components of local RAS may be differently regulated in different organs by a specific stimulus, such as the stimulation of beta-adrenergic receptors.

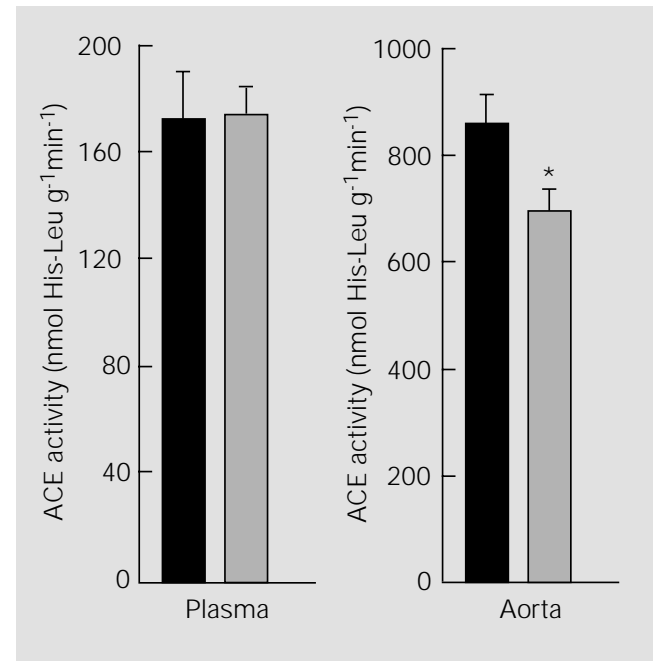

Figure 2 - Angiotensin-converting enzyme (ACE) activity measured in plasma and in aorta homogenates of control rats (black bars, $\mathrm{N}=7$ ) and isoproterenoltreated rats (gray bars, $\mathrm{N}=8$ ). $* \mathrm{P}<0.05$ vs control group (Student t-test).
There is strong evidence supporting the view that isoproterenol acting via beta-adrenoceptors is able to upregulate the cardiac RAS $(9,11,12)$. However, there is no direct evidence to support the idea that this agonist was able to downregulate the aortic RAS. We cannot rule out the possibility that the reduction of arterial pressure produced by isoproterenol treatment may contribute to this finding.

\section{Acknowledgments}

We thank Maria da Glória de Souza Gomes and Enildo Broeto for dedicated technical assistance.

\section{References}

1. Peach S (1977). Renin-angiotensin system: biochemistry and mechanisms of action. Physiological Reviews, 57: 313370.

2. Campbell DJ (1987). Circulating and tissue angiotensin systems. J ournal of Clinical Investigation, 79: 1-6.

3. Unger T, Ganten D \& Lang RE (1986). Tissue converting enzyme and cardiovascular actions of converting enzyme inhibitors. J ournal of Cardiovascular Pharmacology, 8: S75-S81.

4. Lindpaintner $\mathrm{K}, \mathrm{Lu} \mathrm{W}$, Niedermajer $\mathrm{N}$, Schieffer B, J ust H, Ganten D \& Drexler H (1993). Selective activation of cardiac an- giotensinogen gene expression in postinfarction ventricular remodeling in the rat. J ournal of Molecular and Cellular Cardiology, 25: 133-143.

5. Nio $Y$, Matsubara $H$, Murasawa S, Kanasaki M \& Inada M (1995). Regulation of gene transcription of angiotensin II receptor subtypes in myocardial infarction. J ournal of Clinical Investigation, 95: 4654.

6. Hirsch AT, Talness CE, Heribert S, Paul M \& Dzau VJ (1991). Tissue-specific activation of cardiac angiotensin converting enzyme in the experimental heart failure. Circulation Research, 69: 475-482.
7. Hokimoto S, Yasue H, Fujimoto K, Sakata R \& M iyamoto E (1995). Increased angiotensin converting enzyme activity in left ventricular aneurysms of patients after myocardial infarction. Cardiovascular Research, 29: 664-669.

8. Busatto VCW, Cicilini MA \& Mill JG (1997). Increased angiotensin-converting enzyme activity in the left ventricle after infarction. Brazilian J ournal of Medical and Biological Research, 30: 679-687.

9. Nagano M \& Ogihara T (1994). Role of the cardiac renin-angiotensin system in left ventricular hypertrophy. In: Lindpaintner K \& Ganten D (Editors), The Cardiac Re- 
nin-Angiotensin System. Futura Publishing Co., Armonk, NY, 167-182.

10. Bissolli NS, Moysés MR, Vasquez EC \& Cabral AM (1991). Captopril prevents ventricular hypertrophy in sinoaortic denervated rats. Brazilian J ournal of Medical and Biological Research, 24: 191-194.

11. Oliveira $E M$, Koike $M K$, J unqueira $M L$, Oliveira VLL, Pires MD, Fortner PL \& Krieger J E (1996). Isoproterenol-induced hypertrophy increases left ventricular ACE activity and ACE promoter expression in vivo. J ournal of Hypertension, 14: (Suppl 1): S211 (Abstract).

12. Ogiku $N$, Ishida $R$, Saeki $K \&$ Sugiura $M$ (1996). Induction of cardiac angiotensinogen mRNA and angiotensin converting enzyme activity in isoproterenol-induced heart injury. Hypertension Research, 19: 179-187.

13. Santos RAS, Brum J M, Brosninhan $K B$ \& Ferrario CM (1990). The renin-angiotensin system during acute myocardial ischemia in dogs. Hypertension, 15 (Suppl I): I.121I.127.

14. Friedland J \& Silverstein E (1976). A sensitive fluorimetric assay for angiotensin converting enzyme. J ournal of Hypertension, 6 (Suppl 3): S13-S15.

15. Pagano VT \& Inchiosa J r MA (1977). Cardiomegaly produced by chronic beta-adrenergic stimulation in the rat: comparison with alpha-adrenergic effect. Life Sciences, 21: 619-624.

16. Xenophontos $X P$, Watson $P A$, Chua BHL, Haneda T \& Morgan HE (1989). Increased cyclic AMP content accelerates protein synthesis in rat heart. Circulation Research, 65: 647-656.

17. Nagano M, Higaki J \& Nakamura F (1992). Role of cardiac angiotensin II in isoproterenol-induced left ventricular hypertrophy. Hypertension, 19: 708-712.

18. Buchholz RA, Hubbard J W \& Nathan MA (1986). Comparison of 1 hour and 24 hour blood pressure recordings in central or peripheral baroreceptor denervated rats. Hypertension, 8: 1154-1163.

19. Mill J G, Vassallo CM \& Leite CM (1991). Time course of changes in heart rate and sympathetic tone after coronary artery ligation in rats. Brazilian J ournal of Medical and Biological Research, 24: 191-194. 